\title{
Review and Evaluation of Current Design and Management Practices for Land Treatment Units Receiving Petroleum Wastes
}

\author{
J. P. MARTIN and RONALD C. SIMS \\ Utah Water Research Laboratory and \\ Dept. of Civil and Environmental Engineering \\ Utah State University \\ Logan, UT 84322-8200
}

\author{
JOHN MATTHEWS \\ Robert S. Kerr Environmental Research Laboratory \\ U.S. Environmental Protection Agency \\ Ada, OK 74820
}

\begin{abstract}
Land treatment is categorized in the Resource Conservation and Recovery Act of 1976 (RCRA) as one of the land disposal options for managing hazardous wastes. Land treatment relies on detoxification, degradation, and immobilization of hazardous waste constituents within the defined treatment zone to ensure protection of surface water, groundwater, and air. Under the authority of Subtitle C of RCRA, the U.S. Environmental Protection Agency has promulgated regulations governing the treatment of hazardous wastes in land treatment units (40 CRF, Part 264, Subpart M, July, 1982).

This paper describes the land treatment practices used by petroleum waste land treatment $f$ acilities in the U.S. Information obtained for thirteen fullscale 1 and treatment facilities included types of waste 1 and treated, characterization of 1 and treated wastes, waste application rates (loading rates), waste application frequencies, and management practices used at the treatment units.

Engineering design matrices which illustrate the relationships among waste application rate, application frequency, and waste degradation rate, and the effect of these parameters on stabilized concentrations during the active life a unit were developed. Waste degradation half-life and waste application frequency were observed to have greater influence in determining the stabilized weight percentage of oil in the treatment soil than waste application rate. A three-dimensional graph was developed as an example of how design matrices can be used as engineering/management aids for petroleum land treatment site design and operation.
\end{abstract}

\section{INTRODUCTION}

Land treatment is the controlled application of 1 iquid, solid, and semisolid wastes to the upper zone, usually the top 6 to 12 inches, of a soil system for achieving treatment and simultaneous safe ultimate disposal. Objectives of 1 and treatment are: 1) to prevent off-site migration of hazardous constituents via migration to ground and surface waters and transport through the atmosphere, and 2) to render the wastes less or non-hazardous through treatment. Treatment includes the processes of degradation, transformation, and immobilization of hazardous constituents in a soil/waste mixture. 
Land treatment of petroleum industry wastes involves the immobilization of metal constituents and the immobilization and biodegradation of organic constituents. Land treatment has been used as a waste management technology by the U.S. petroleum industry for more than 25 years.

Figure 1 shows the location of petroleum industry 1 and treatment facilities in the United States. The U.S. Environmental Protection Agency (EPA) has given an estimate of 1001 and treatment facilities for the U.S. petroleum industry (1).

This paper is based on a subset of thirteen presently operating petroleum refinery facilities that represent the geographical distribution of refineries in the U.S. Information was obtained specifically with respect to factors addressed by the EPA concerning regulations governing the treatment of hazardous waste in land treatment facilities as specified in 40 Code of Federal Regulations (CFR), Part 264, Subpart M, July 1982, even though no full-scale facility has been issued a permit to land treat hazardous waste at this time. The information obtained included:

- types of wastes 1 and treated;

- characterization of wastes, including specific inorganic and organic constituents, and of waste treatment sites;

- waste application methods, rates, and frequencies; and

- operation and management of 1 and treatment units.

A design and management matrix was developed to illustrate the effects of design factors (application rates, application frequencies) and site factors (biodegradation half-life for the soil/waste mixture) on waste treatment. Waste treatment was characterized as the stabilized oil/soil concentration resulting from long-term waste application. The objectives of this paper are to summarize the information obtained and to indicate the integrated effects of design and management factors on petroleum waste treatment.

\section{CURRENT APPROACH TO LAND TREATMENT IN THE PETROLEUM INDUSTRY}

\section{Waste Characterization}

Specific waste streams that are land treated at the thirteen facilities are summarized in Figure 2. Four petroleum wastes most frequently 1 and treated, in decreasing order of frequency, are API separator sludge, slop oil emulsion solids, dissolved air flot at ion froth (DAF), and waste activated sludge.

The physical properties of wastes that are land treated at the facilities are presented in Figure 3. The physical characterization of the wastes ranged from a minimum oil concentration of 0.1 percent with 96 percent water and 3.9 percent solids to a maximum oil concentration of 17.4 percent with 38.6 percent water and 44 percent solids. The mean physical properties of the wastes were 12 percent oil, 70 percent water, and 18 percent solids.

Specific inorganic and organic hazardous constituents identified in petroleum wastes are presented in Figures 4 and 5 , respectively.

Climatic, Soil, and Physical

Characterization

Climatic, soil, and physical site characteristics for individual facilities are presented in Tables 1 through 4, respectively. Climatic characteristics listed in Table 1 indicate a large range in atmospheric temperatures, relative humidity, and precipitation for the thirteen sites. Soil characteristics listed in Table 2 also indicate a 1 arge range in parameters that may affect land treatment, with the exception of $\mathrm{pH}$ values, including permeability, erodibility, texture, and cation exchange capacity. Physical site characteristics listed in Tables 3 and 4 include the ranges in depth to bedrock, water table, and usable aquifer, and identify site modifications for each facility. Thus, the sites for the thirteen facilities represent a wide variety of climate, soil, and physical 


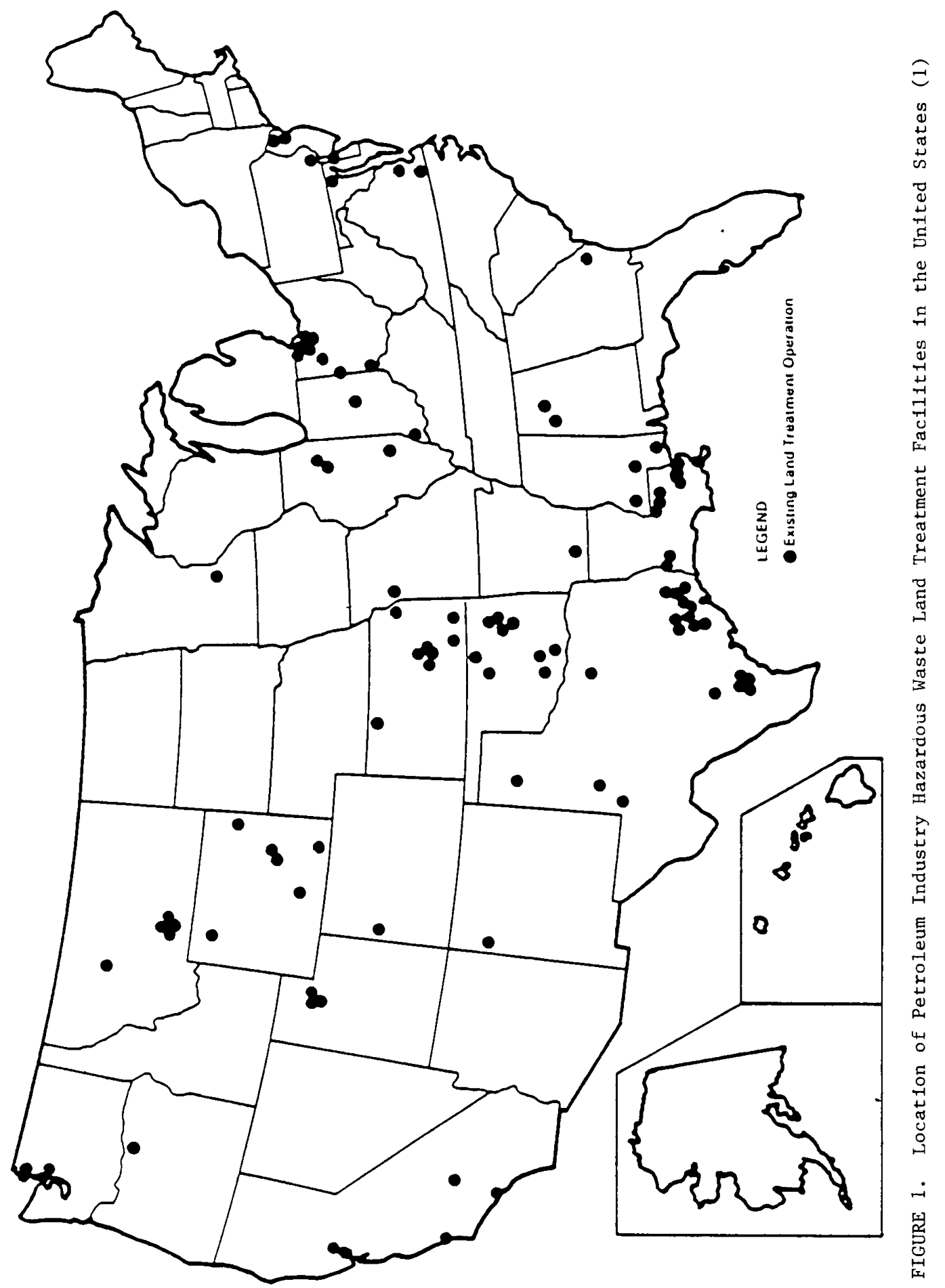









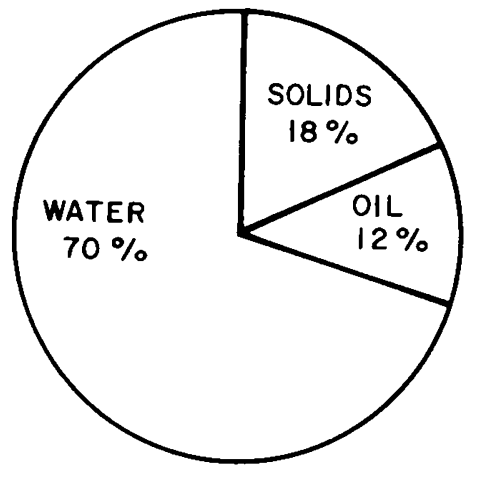

A.

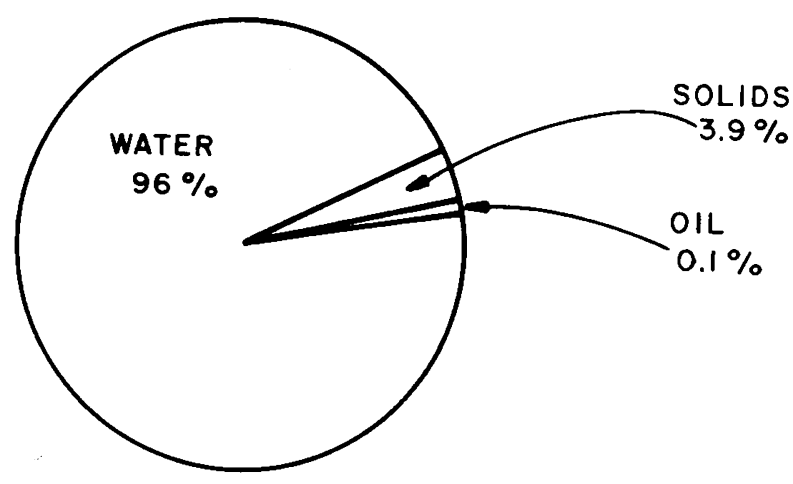

c.

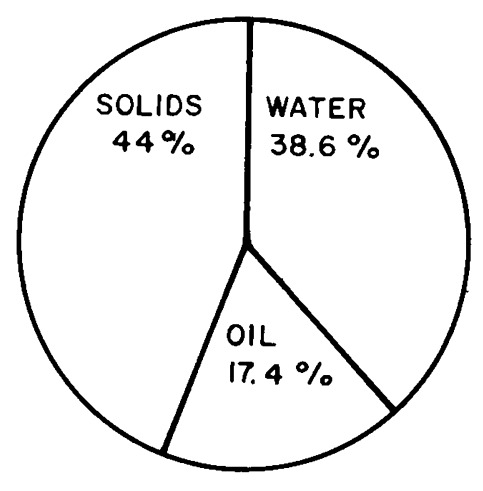

B.

FIGURE 3. Physical Characterization of Land Treated Wastes in the Survey of Thirteen Petroleum Refinery Facilities: A) Facility with a Mean oil Concentration, B) Facility with a Maximum $0 i 1$ Concentration, and C) Facility with a Minimum $0 i 1$ Concentration. 


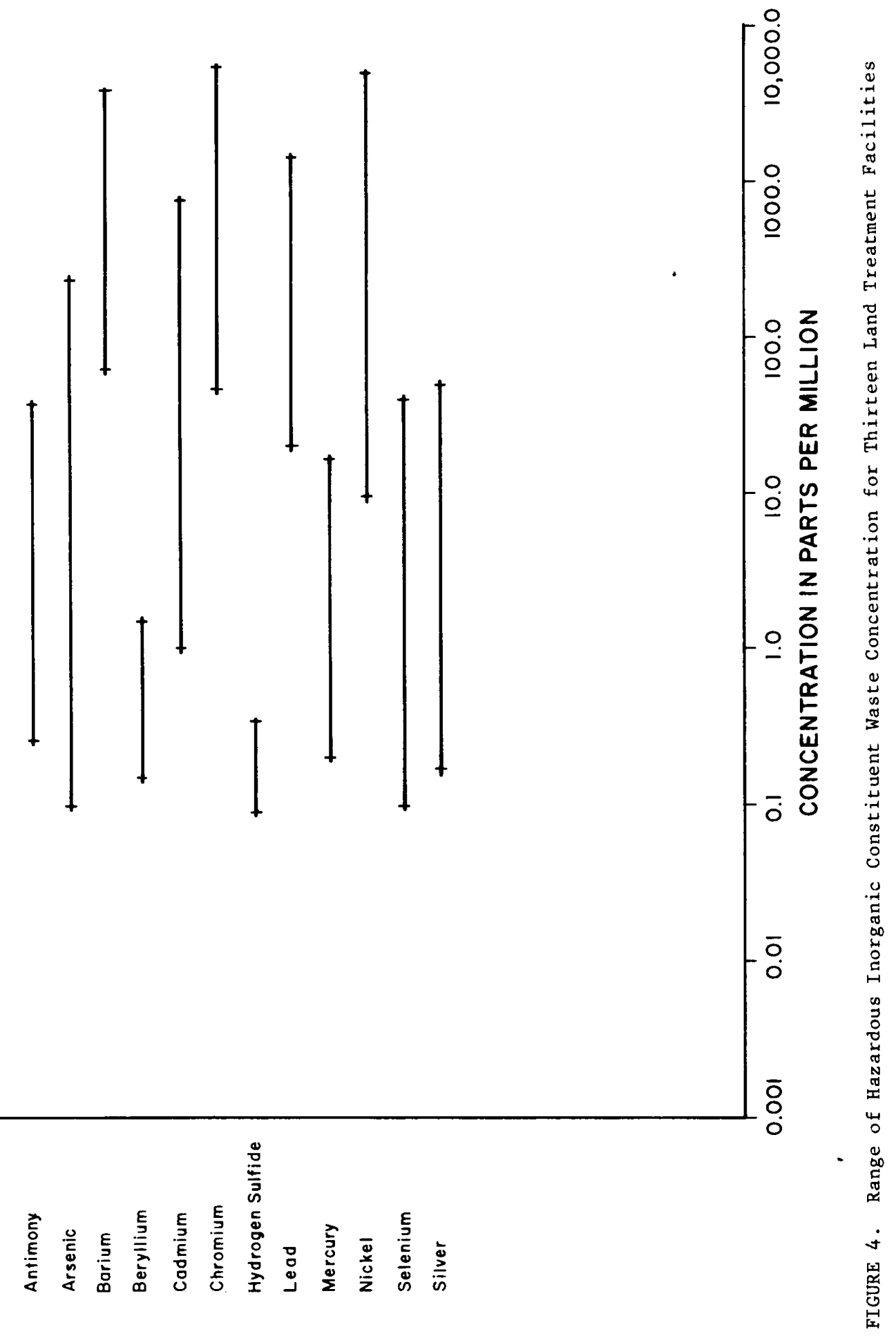



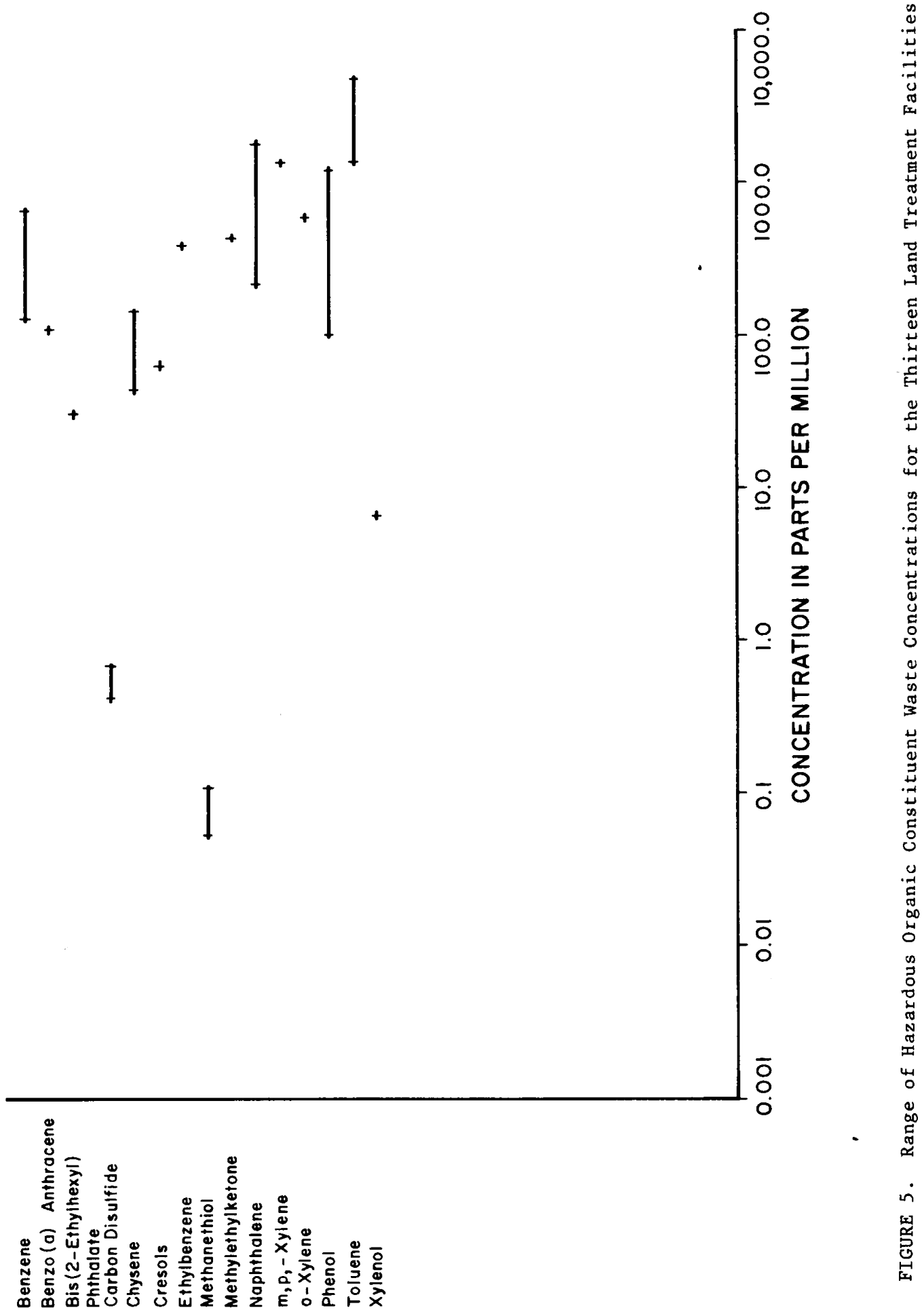
TABLE 1 .

Climatic Characteristics of Land Treatment Facilities

\begin{tabular}{|c|c|c|c|c|c|c|}
\hline \multirow[b]{2}{*}{ Parameter } & \multicolumn{6}{|c|}{ Facility Code } \\
\hline & 01 & 02 & 03 & 04 & 05 & 06 \\
\hline \multicolumn{7}{|l|}{ Atmospheric Temperature $\left({ }^{\circ} \mathrm{C}\right)$} \\
\hline Average Annual Minimum & 4 & 10 & -15 & -18 & 12 & -8 \\
\hline Average Annual Maximum & 14 & 32 & 24 & 32 & 21 & 31 \\
\hline Daily Minimum & -27 & -18 & -26 & -34 & -1 & -13 \\
\hline Daily Maximum & 40 & 43 & 46 & 40 & 43 & 37 \\
\hline \multicolumn{7}{|l|}{ Relative Humidity $(\%)$} \\
\hline Average Annual & 74 & 80 & $-*$ & 70 & 70 & 50 \\
\hline Extreme Daily & 100 & 100 & - & 100 & - & 100 \\
\hline \multicolumn{7}{|l|}{ Annual Precipitation (meters) } \\
\hline Tota 1 & 0.8 & 1.5 & 0.9 & 0.7 & 0.3 & 0.7 \\
\hline Snow & 1.0 & 0 & 0 & 1.2 & 0 & 0.1 \\
\hline \multicolumn{7}{|l|}{ Rainfal 1 Intensity (meters) } \\
\hline 24 Hour Maximum & 0.2 & 0.3 & - & - & 0.2 & 0.1 \\
\hline \multicolumn{7}{|l|}{$\begin{array}{l}\text { Average Number of Days } \\
\text { of Rain and Snow }\end{array}$} \\
\hline 0.05 Meter Rain or Greater & - & 16 & - & - & 1 & 0 \\
\hline \multirow[t]{2}{*}{0.0254 Meter Snow or Greater } & - & 0 & - & - & 0 & 1 \\
\hline & \multicolumn{6}{|c|}{ Facility Code } \\
\hline Parameter & 07 & 08 & 10 & 11 & 12 & 13 \\
\hline \multicolumn{7}{|l|}{ Atmospheric Temperature $\left({ }^{\circ} \mathrm{C}\right)$} \\
\hline Average Annual Minimum & 2 & - & $>10$ & -3 & -5 & 27 \\
\hline Average Annual Maximum & 14 & - & - & 20 & 22 & 43 \\
\hline Daily Minimum & -39 & - & - & 10 & - & 4 \\
\hline Daily Maximum & 41 & - & - & 31 & - & 48 \\
\hline \multicolumn{7}{|l|}{ Relative Humidity (\%) } \\
\hline Average Annual & 54 & - & - & 65 & - & 40 \\
\hline Ext reme Daily & 71 & - & - & 93 & - & 60 \\
\hline \multicolumn{7}{|l|}{ Annual Precipitation (meters) } \\
\hline Total & 0.4 & 1.3 & 0.1 & 0.8 & 0.4 & 0.05 \\
\hline Snow & 1.4 & - & - & - & 0.05 & 0 \\
\hline \multicolumn{7}{|l|}{ Rainfall Intensity (meters) } \\
\hline 24 Hour Maximum & 0.06 & - & - & 0.04 & 0.08 & 0.05 \\
\hline \multicolumn{7}{|l|}{$\begin{array}{l}\text { Average Number of Days } \\
\text { of Rain and Snow }\end{array}$} \\
\hline 0.05 Meter Rain or Greater & 2 & - & - & - & 0 & 0 \\
\hline 0.0254 Meter Snow or Greater & 20 & - & - & - & 10 & 0 \\
\hline
\end{tabular}

*Information was not available. 


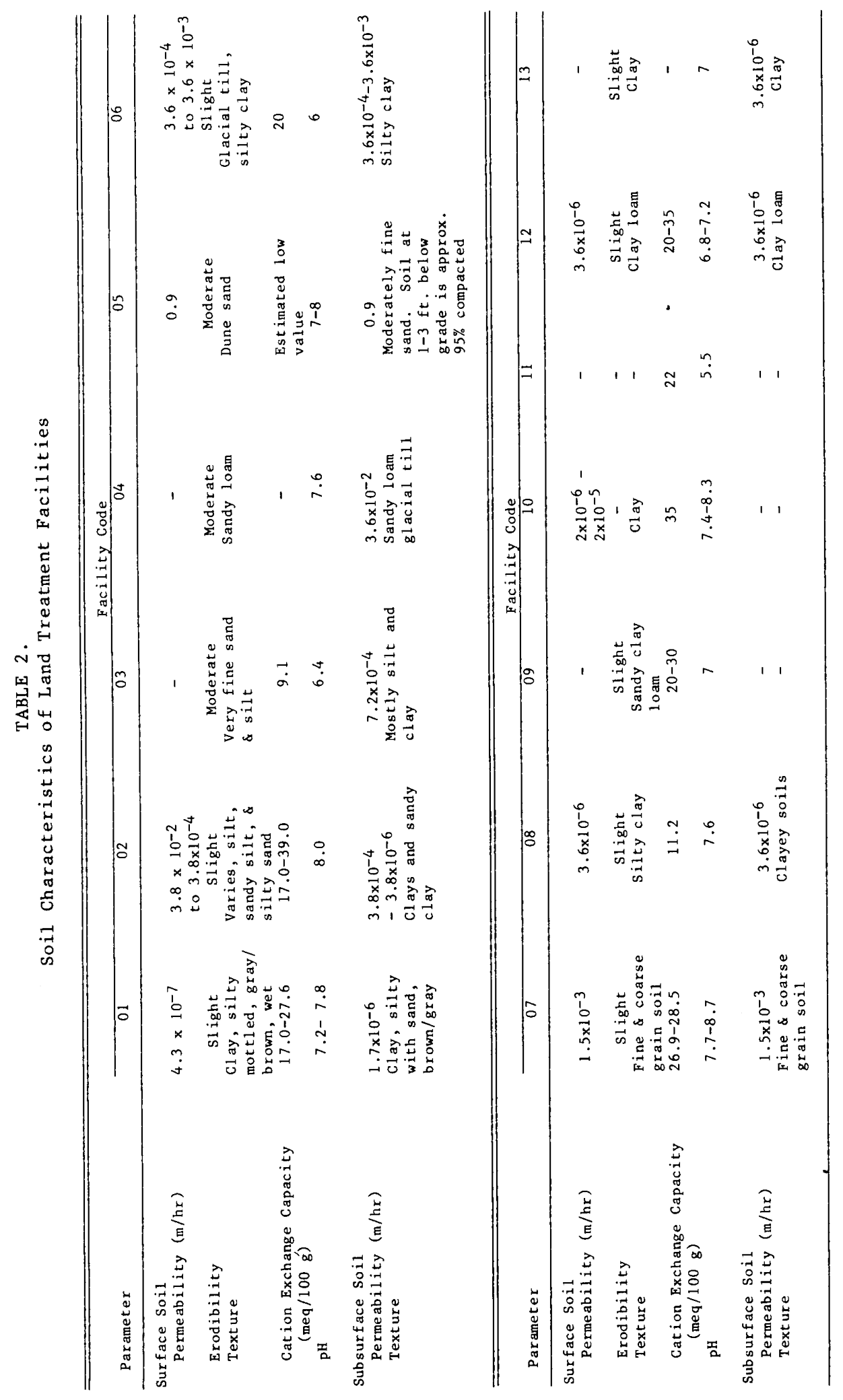




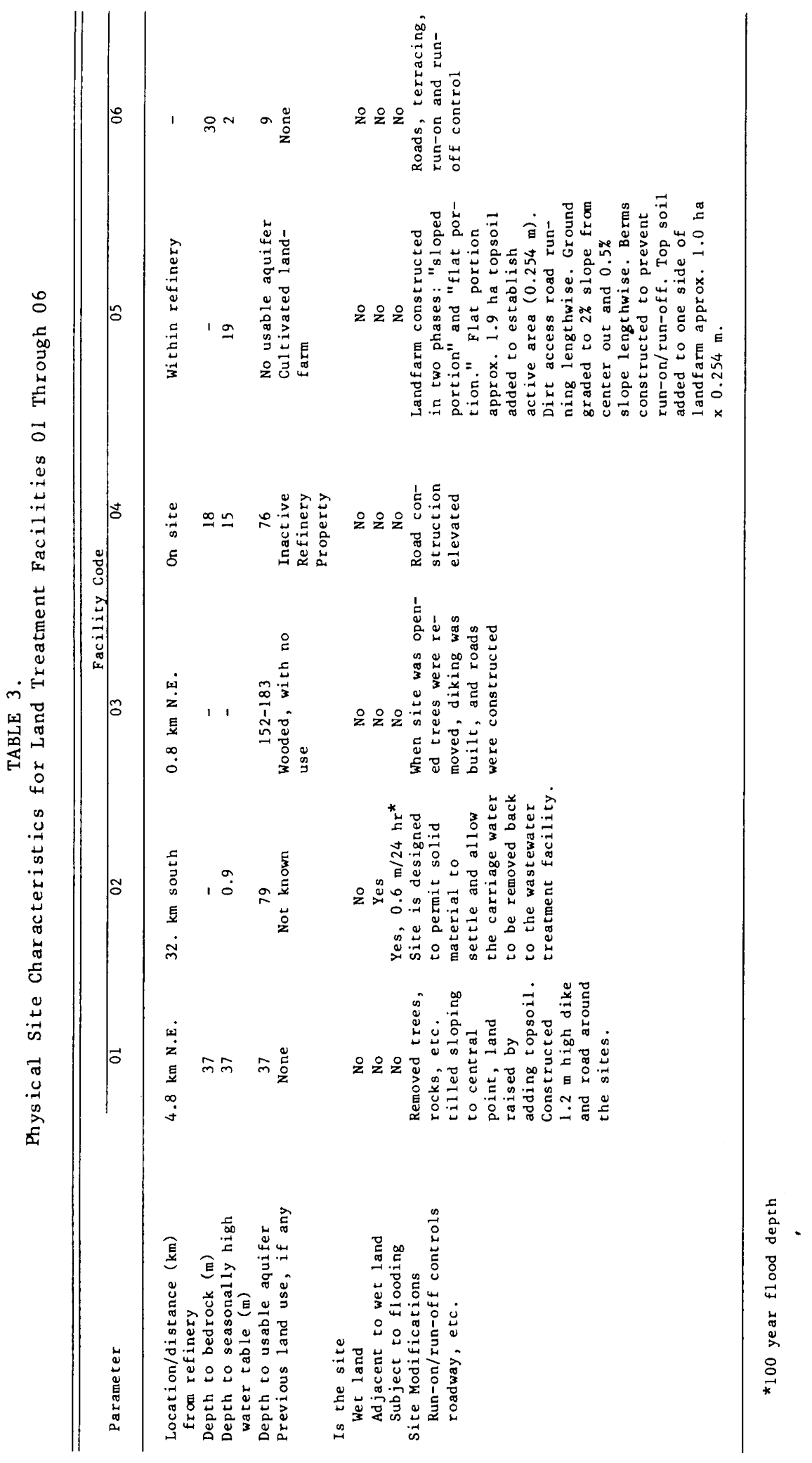




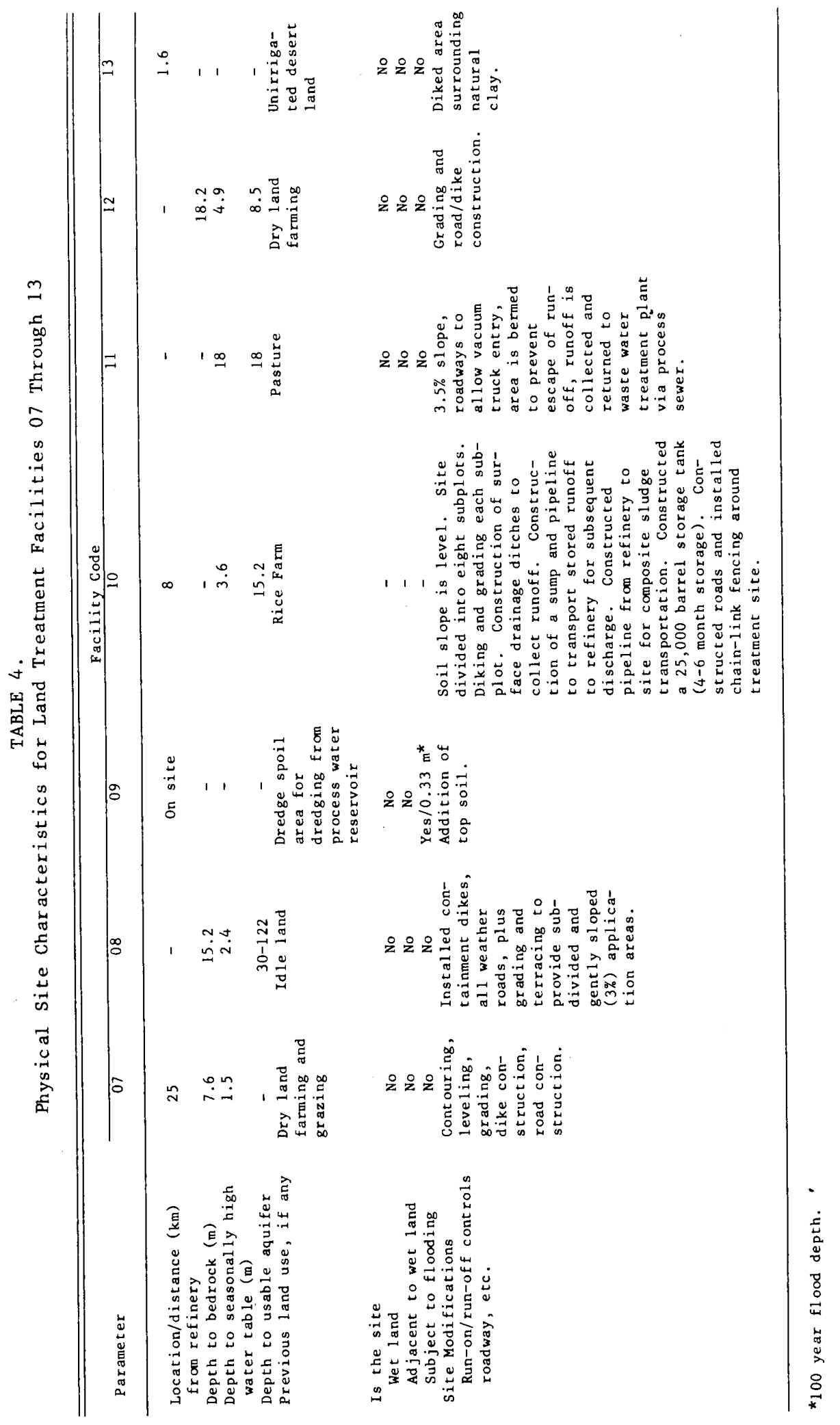


site characteristics that are adequate for land treatment of petroleum refinery wastes.

\section{Operation/Management Characterization}

Facility operational characteristics are presented in Tables 5 and 6 . Land treatment areas for the thirteen facilities ranged from 2.8 hectares to 85 hectares, and waste incorporation depth ranged from 0.15 meters to 0.66 meters. The number of months the facilities were actively used per year varied from 6 months (colder climates) to 12 months (warmer climates). Waste application methods included spraying, surface spreading, subsurface injection, and vacuum truck hose application. Maximum waste application rates ranged from 0.004 weight percentage of oil in soil (oil/soil concentration) per application to 8 percent oil/soil concentration per application. Waste application frequencies varied from daily to yearly depending upon waste generation. Approximately 70 percent of the facilities added amendments to the soil for waste degradation enhancement, including NPK fertilizer and 1 ime.

\section{Design Matrix for Evaluating Treatment}

Major design and site factors affecting waste treatment include waste application rate and application frequency, and waste degradation rate as influenced by site/soil characteristics. Waste application rate, or loading rate, is a function of oil concentration in the waste and the 1 and area for waste treatment, as suming a conventional $15 \mathrm{~cm}$ depth of incorportion. Waste application frequency is generally a function of production rate and waste quantity. Waste degradation rate may be a function of site and soil characteristics including climatic conditions, soil temperature and moisture, soil texture and chemistry, and operation/management practices (2). Degradation rate may also be a function of the loading rate, especially when the waste exerts a toxic effect on microorganisms (3). Degradation rates are generally expressed as half-1ife, or the time required to decrease the original concentration by one-half, and may incorporate all of the site/soil factors identified above. Degradation includes biodegradation as the primary mechanism, but may also include some volatilization losses. Degradation kinetics, expressed as half-lives, are generally modeled based on zero order or first order reactions.

A design matrix was developed to illustrate an approach for evaluating the combined effects of design factors, including waste application rate and application frequency, and site factors, evaluated as biodegradation half-life, on waste treatment. Waste treatment was characterized as the stabilized, steady-state, oil/soil concentration resulting from long-term, repeated, waste application. Waste application rates and application frequencies for the facilities evaluated are 1 isted in Tables 5 and 6 . Due to the dearth of information obtained concerning oil degradation kinetics for the facilities evaluated, a zero order kinetic model was used with literature values for half-lives. A range of half-lives was used in order to evaluate the effects of site/soil characteristics on treatment. The U.S. EPA (4) described the use of zero order kinetics and half-lives for 1 and treatment systems treating petroleum wastes. Overcash and Pal (5) also described oil degradation in soil systems in zero-order kinetic terms. However, other findings for oil and especially for individual constituents suggest that first order reactions $c$ an also be used to represent degradation reactions in 1 and treatment systems $(6,7,8,9)$. Zero order kinetics was used because it is one conventional approach for handing rate data and for describing oil degradation in land treatment systems. A similar design matrix could be developed based on first order kinetics to illustrate the effects of design factors and site factors (temperature) on waste treatment. Additional factors that may influence the actual rate of degradation used in developing a design matrix include acclimation of the soil microbial community to the waste and a possible overloading of the biological community at high loading rates or loading frequencies. The primary purpose for applying a kinetic approach to the data obtained, and for using a 


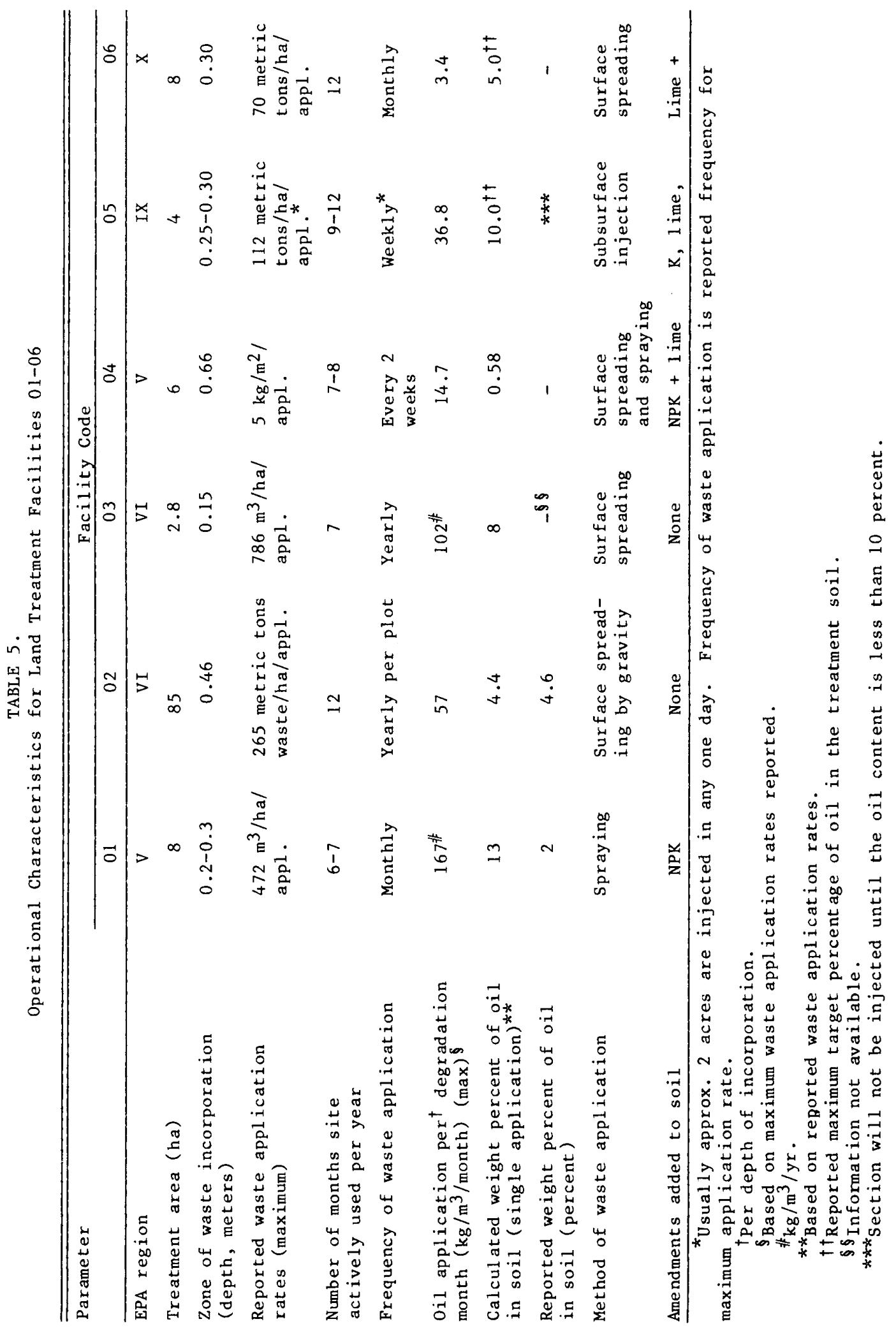


TABLE 6 .

Operational Characteristics for Land Treatment Facilities 07-13

\begin{tabular}{|c|c|c|c|c|c|c|c|}
\hline \multirow[b]{2}{*}{ Parameter } & \multicolumn{7}{|c|}{ Facility Code } \\
\hline & 07 & 08 & 09 & 10 & 11 & 12 & 13 \\
\hline EPA Region & VIII & v & VI & VI & $\mathrm{x}$ & ' viII & IX \\
\hline $\begin{array}{l}\text { Treatment } \\
\text { area (ha) }\end{array}$ & 5.7 & 4.6 & 6.1 & 20 & 2.8 & 4.8 & 2.0 \\
\hline $\begin{array}{l}\text { Zone of waste } \\
\text { incorporation } \\
\text { (depth, meter) }\end{array}$ & 0.20 & 0.20 & 0.15 & 0.20 & 0.30 & 0.15 & 0.25 \\
\hline $\begin{array}{l}\text { Reported } \\
\text { waste appli- } \\
\text { cat ion rates } \\
\text { (maximum) }\end{array}$ & $\begin{array}{l}20815 \mathrm{~kg} \\
\text { waste } / \mathrm{ha} / \\
\text { applica- } \\
\text { tion }\end{array}$ & $\begin{array}{l}76118 \mathrm{~kg} \\
\text { waste/ha/ } \\
\text { application }\end{array}$ & $\begin{array}{l}59 \cdot \mathrm{m}^{3} \text { waste } / \mathrm{ha} / \\
\text { application }\end{array}$ & $\begin{array}{l}3.5 \mathrm{~kg} \text { oil } 1 / \mathrm{m}^{3} / \\
\text { appl ication }\end{array}$ & $\begin{array}{l}772 . \mathrm{kg} / \\
\text { waste/ha/ } \\
\text { application }\end{array}$ & $\begin{array}{l}1050 \mathrm{~kg} \text { oil/ } \\
\text { ha/applica- } \\
\text { tion }\end{array}$ & $\begin{array}{l}2.4 \mathrm{~m}^{3} \mathrm{oil} / \mathrm{ha} / \\
\text { appl ication }\end{array}$ \\
\hline $\begin{array}{l}\text { Number of } \\
\text { months site } \\
\text { actively used } \\
\text { per year }\end{array}$ & 8 & 6 & 10 & 12 & 12 & 10 & 12 \\
\hline $\begin{array}{l}\text { Frequency of } \\
\text { waste appli- } \\
\text { cation }\end{array}$ & $\begin{array}{l}\text { Every } 3 \\
\text { months }\end{array}$ & $\begin{array}{l}2 \text { to } 3 \\
\text { times/week }\end{array}$ & Monthly & Monthly & Monthly & Monthly & 5 times/week \\
\hline $\begin{array}{l}\text { Oil applica- } \\
\text { tion per* } \\
\text { degradation } \\
\text { month ( } \mathrm{kg} / \mathrm{m}^{3} / \\
\text { month) } \max { }^{\dagger}\end{array}$ & 0.64 & 0.18 & 0.11 & 4.16 & 2.31 & 4.21 & 1.83 \\
\hline $\begin{array}{l}\text { Calculated } \\
\text { weight per- } \\
\text { cent of } \\
\text { oil in soil } \\
\text { (single appli- } \\
\text { cation) }\end{array}$ & 0.05 & 0.0036 & 0.8 & 0.28 & 0.18 & 0.34 & 0.35 \\
\hline $\begin{array}{l}\text { Reported } \\
\text { weight per- } \\
\text { cent of oil } \\
\text { in soil } \\
\text { (percent) }\end{array}$ & $-* \star \star *$ & - & - & - & - & - & - \\
\hline $\begin{array}{l}\text { Method of } \\
\text { waste appli- } \\
\text { cation }\end{array}$ & $\begin{array}{l}\text { Surface } \\
\text { spraying/ } \\
\text { spreading }\end{array}$ & $\begin{array}{l}\text { Surface } \\
\text { spreading }\end{array}$ & $\begin{array}{l}\text { Surface } \\
\text { apreading }\end{array}$ & $\begin{array}{l}\text { Subsurface } \\
\text { injection }\end{array}$ & $\begin{array}{l}\text { Vacuum } \\
\text { truck hose }\end{array}$ & $\begin{array}{l}\text { Surface } \\
\text { spreading }\end{array}$ & Surface injection \\
\hline $\begin{array}{l}\text { Amendments } \\
\text { added to soil }\end{array}$ & $\begin{array}{l}\text { Lime and } \\
\text { fertilizer }\end{array}$ & $\begin{array}{l}\text { Lime and } \\
\text { fertilizer }\end{array}$ & $\begin{array}{l}\text { Lime and (NPK) } \\
\text { fertilizer }\end{array}$ & None & $\begin{array}{l}\text { Lime and } \\
\text { fertilizer } \\
\text { (once in } 3 \\
\text { years) }\end{array}$ & $\begin{array}{l}\text { Lime and } \\
\text { (NPK) } \\
\text { fertilizer }\end{array}$ & None \\
\hline
\end{tabular}

*Per depth of waste incorporation.

Based on maximum waste application rates reported.

Based on reported waste application rates.

** Information not available. 
range of values for biodegradation half-lives (site/soil characteristics), was to generate a matrix for evaluating the effect of design and site variables, and the interrelationships of these factors, on waste treatment.

The methodology used for calculating stabilized oil/soil concentrations is illustrated in Table 7. As indicated in Table 7 for Facility 05, using a 125 day half-life, 0.22 percent application rate, and a frequency of once every 7 days for 12 months, an oil/soil concentration value of 5.9 percent was predicted to occur after 1 year (week 52). After 5 years of continued use, the residual weight percentage of oil in the soil stabilized at 7.6 percent. Using a 304 day half-1ife value, the residual oil/soil concentration stabilized at 18.9 percent after 11 years of continued use (Table 8). Results indicated that the time required for a 1 and treatment site to stabilize is primarily a function of the waste half-life, within the range of half-lives investigated, and to a lesser extent a function of the application weight percentage of oil' in the soil. The calculated times required for treatment stabilization ranged from an average of 4 years to 15 years for 60 day and 304 day half-lives, respectively. Predicted stabilized oil/soil concentration values are presented in Table 8 for ten of the thirteen facilities.

The predicted values for stabilized oil/soil concentrations (Table 8), using the methodology described, agree well with the results obtained for several other full scale petroleum refinery land treatment facilities in the U.S. (10). Steady-state oil content in the zone of incorporation for full scale facilities reported by Brown (10) ranged from 3.5 percent to 8 percent.

A graphical representation of predicted stabilized residual oil/soil concentration values for eight of the thirteen facilities presented in Table 8 is shown in Figure 6. Waste degradation half-1ife is represented on the $x$-axis, waste application frequency is on the $z$-axis, and stabilized residual oil/soil concentration is on the y-axis. The family of curves represents different waste application rates. A three-dimensional form was used in Figure 6 to visualize the effect of waste application frequency and changes in application frequency on the stabilized residual oil/soil concentration values. For example, Facility 03 (identified as $G$ in Figure 6), using a 304 day half-1ife, 8.0 percent application rate, and a frequency of once per year, resulted in a 5.3 percent stabilized residual oil/soil concentration. However, Facility 09 (identified as $D$ in Figure 6 ), using the same half-1ife, 0.8 percent application rate, and a frequency of once a month for 10 months per year, resulted in a 13.8 percent stabilized residual oil/soil concentration value. Similarly for half-lives of 60 days, 125 days, and 146 days, stabilized residual oil/soil concentration values for Facility 09 were 9 fold, 4 fold, and 2.9 fold greater than Facility 03 , respectively. Thus a 10 fold increase in waste application frequency resulted in a greater stabilized residual oil/soil concentration value even though the application rate was 10 fold less.

The interrelationships among waste application frequency, waste degradation half-life, and stabilized oil/soil concentration are illustrated in Figure 7 for an application rate of 0.3 percent oil in the soil and equal time intervals between waste application events. Matrices, such as Figure 7, may be useful as engineering aids for designing and managing petroleum land treatment facilities. An important parameter that may be managed is the waste degradation half-1ife. Pilot/bench scale studies can be utilized to evaluate half-life values for specific waste/site/soil management conditions (11). Waste application rates can be determined from the quantity of waste produced, waste oil concentration, and the 1 and area required for actual treatment (see example in Table 7). Waste application frequency is a function of waste quantity and waste generation frequency. With any three of the four parameters known (half-life, application rate, application frequency, and stabilized residual oil/soil concentration), and assuming that half-life is independent of loading rate for the range of loading rates commonly used, the fourth parameter can then be determined.

Treatment area, waste incorporation zone, waste quantity applied, and waste application frequency are functions of the waste application rate and may also be obtained from Figure 7. For example, consider that a decision has been made, based on toxicity of the waste to soil microorganisms (5), to 1 imit the stabilized residual oil/soil concentration to 5.0 percent. If bench scale tests 
TABLE 7 .

Example Calculations for Determining Values for Facility 05

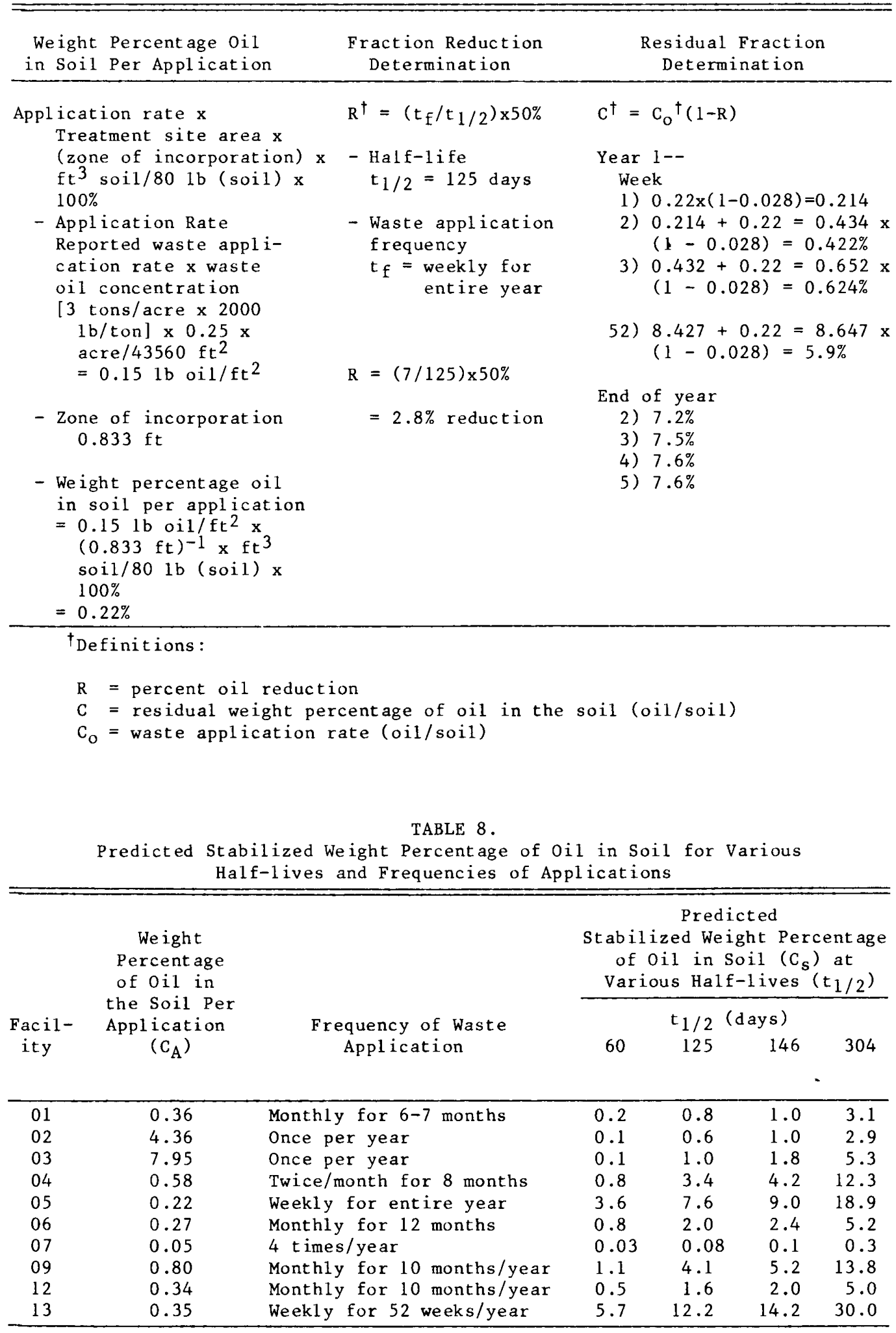




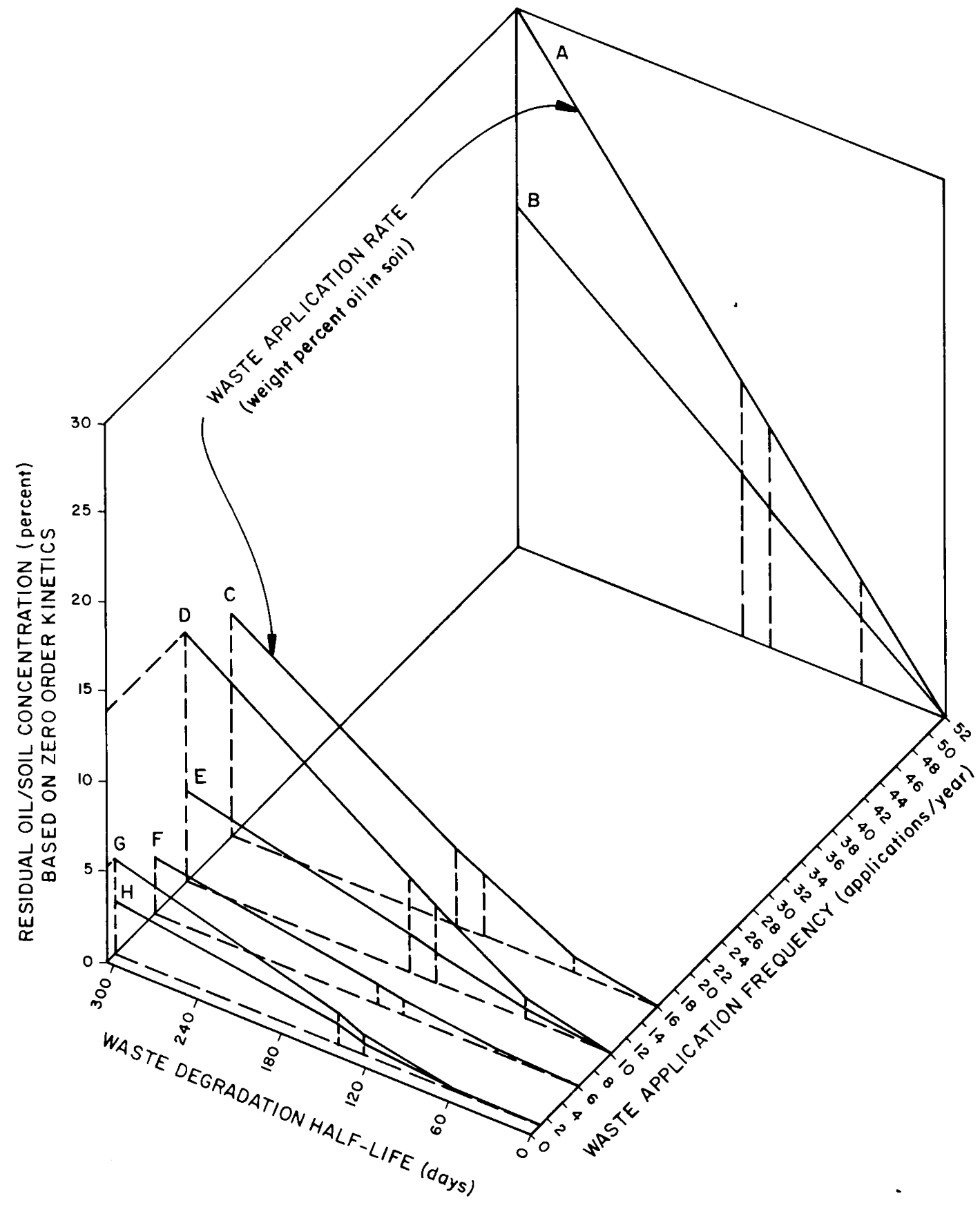

FIGURE 6. Facility Residual 0i1/Soil Concentration as a Function of Waste Degradation Half-Life, Waste Application Frequency from Table 8, and Waste Application Rate. Waste Application Rate (Weight Percent 0il in the Soi1) Key: A) $0.35 \%$, B) $0.22 \%$, C) $0.58 \%$, D) $0.80 \%$, E) $0.34 \%$, F) $0.36 \%$, G) $7.95 \%$, and H) $4.36 \%$ 


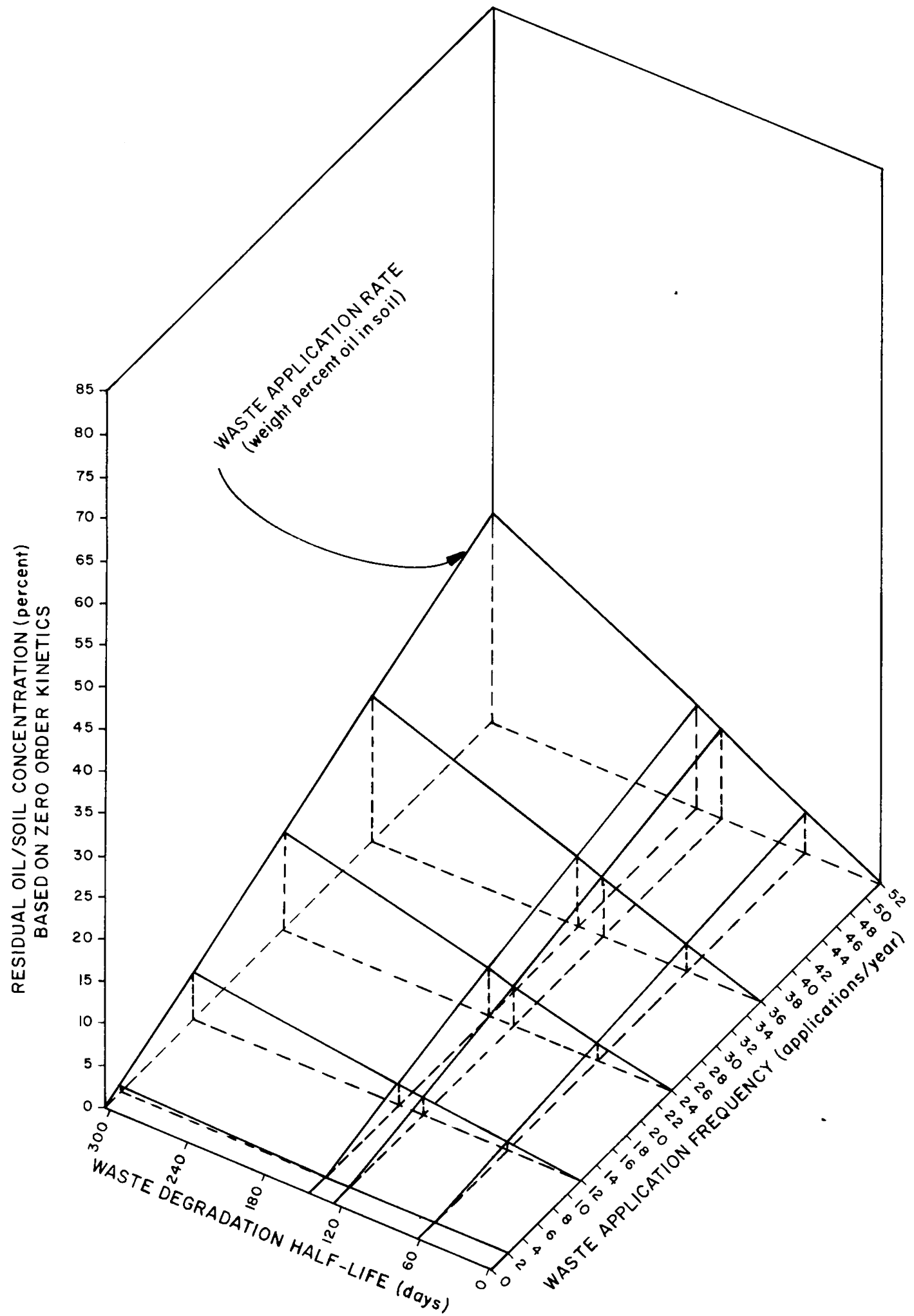

FIGURE 7. Calculated Residual Oil/Soil Concentration as a Function of Waste Degradation Half-Life, Waste Application Frequency, and 0.3 Percent Waste Application Rate 
indicate a 146 day waste degradation half-1ife, from Figure 7, a frequency of 24 applications per year using a 0.3 percent waste application rate will provide the targeted stabilized residual oil/soil concentration value. By using the calculations presented in Table 7, values for treatment area, waste incorporation zone, and waste quantity applied can be determined.

\section{SUMMARY}

Information related to U.S. EPA regulations pertaining to petroleum land treatment practices was obtained from thirteen full-scale 1 and treatment facilities. Specific information included types of waste land treated, characterization of 1 and treated wastes, waste application rates, waste application frequencies, and waste management practices used at the treatment units.

From this information, waste oil degradation, in terms of stabilized weight percentage of oil in the treatment soil during the active life of the units (oil/soil concentration), was evaluated as a function of waste degradation half-life, waste application frequency, and waste application rate. A methodology was used to develop a three-dimensional graph to visualize the interrelationships of these parameters and the effects these parameters have on stabilized oil/soil concentration. Predicted values using the methodology agreed well with results obtained for full scale petroleum land treatment facilities in the U.S. It appears that waste degradation half-life and waste application frequency have a greater influence in determining stabilized oil/soil concentrations than waste application rate.

An additional three-dimensional graph was presented as an example engineering/ management aid. The graph illustrates the relationships, for a constant waste application rate, among waste degradation half-life, waste application frequency, and residual oil/soil concentration. Also, site treatment area, waste incorporation zone, and waste quantity can be calculated from the three-dimensional graph.

\section{RECOMMENDATIONS}

This paper provides information regarding the practice of managing petroleum refinery wastes at land treatment facilities. More detailed information, including on-site observation and sampling, would be required to determine how effectively these wastes are being treated, any adverse environmental impacts, and justification for a particular treatment approach. Additional information is needed pertaining to the quality and quantity of waste organic hazardous constituents in oil waste, the actual quantity of each waste that is applied, the frequency of waste application, and procedures used for the application of wastes that are stored at a facility during inactive periods. The weight percentage of oil in the soil prior to each waste application and at intervals of time is required in order to calculate oil degradation rates, half-lives, and oil concentrations in soil as a function of time. Concentrations of specific organic hazardous constituents in soil before and after waste applications are also needed to calculate concentrations and degradation rates for each specific constituent of concern.

\section{ACKNOWLEDGMENTS}

This work was sponsored by the U.S. Environmental Protection Agency, Robert S. Kerr Environmental Research laboratory, Ada, Ok, urider cooperative agreement rumber CR810979-02. John E. Matthews was the project officer. This work has not been subjected to the Agency's peer review and therefore does not necessarily reflect the views of the agency, and no official endorsement should be inferred. 
1. Brown, K. W. and Associates, A Survey of Existing Hazardous Waste Land Treatment Facilities in the United States. Prepared for the U.S. Environmental Protection Agency, Contract No. 68-03-2943, 1981.

2. Sims, R. C., Sorensen, D. L., Sims, J. L., McLean, J. E., Mahmood, R., and Dupont, R. R., Review of In Place Treatment Techniques For Contaminated Surface Soils, EPA-540/2-84-003a and b, office of Solid Waste and Emergency Response, U.S. Environmental Protection Agency, Cincinnati, Ohio, Sept. 1984 .

3. Sims, R. C., Loading Rates and Frequencies for Land Treatment Systems, In: Land Treatment, A Hazardous Waste Management Alternative, Loehr, R. C. and Malina, J. F. (Eds.), Water Resources Symposium Number Thirteen, Center for Research in Water Resources, College of Engineering, The University of Texas at Austin, 1986.

4. U.S. Environmental Protection Agency, Hazardous Waste Land Treatment, SW-874, Revised Edition, Office of Solid Waste and Emergency Response, U. S. Environmental Protection Agency, Cincinnati, Ohio, April 1983.

5. Overcash, M. R., and Pal, D., In: Design of Land Treatment Systems for Industrial Wastes--Theory and Practice, Ann Arbor Science Publishers, Inc., Ann Arbor, Michigan, 1981 .

6. Loehr, R. C., Martin, J.H., and Neuhauser, E. F., Disposal of Oily Wastes by Land Treatment, Report to 38th Annual Purdue Industrial Waste Conference, Purdue University, West Lafayette, Indiana, May 1983.

7. Goring, C. A. I., Laskowski, D. A., Hamaker, J. W., and Miekle, R. W., In: Environmental Dynamics of Pesticides, Haque, R., and Freed, V. H. (Eds.), P1enum, N.Y., 1975 .

8. Hamaker, J. W., and Goring, C. A. I., In: Bound and Conjugate Pesticide Residues, Kaufman, D. D. et al. (Eds.), ACS Symposium, Series 29, Washington, D.C., 1976 .

9. Sims, R. C., and Overcash, M. R., Fate of Polynuclear Aromatic Compounds (PNAs) in Soil-Plant Systems, Residue Reviews, 88:1-68, 1983.

10. Brown, K. W., and Deue1, L. E., An Evaluation of Subsurface Conditions at Refinery Landform Sites, Prepared for the American Petroleum Institute and the Environmental Protection Agency, Grant No. CR 807868.

11. Sims, R. C., Management of Soil Systems to Optimize Treatment of Polynuclear Aromat ic Compounds, In: Proceedings of the First Annual Hazardous Materials Management Conference/Southwest, Houston, Texas, October 31-November 2, 1984 .

Ronald C. Sims

Utah Water Research Laboratory

Utah State University

Logan, UT 84322-8200 